\title{
Novel poly(L-lactic acid)/hyaluronic acid macroporous hybrid scaffolds: Characterization and assessment of cytotoxicity
}

\author{
J. C. Antunes, ${ }^{1,2}$ J. M. Oliveira, ${ }^{1,2}$ R. L. Reis, ${ }^{1,2}$ J. M. Soria, ${ }^{3}$ J. L. Gómez-Ribelles, ${ }^{4,5,6}$ J. F. Mano ${ }^{1,2}$ \\ ${ }^{1} 3 B^{\prime}$ 's Research Group-Biomaterials, Biodegradables and Biomimetics, Univ. Minho, Headquarters of the European Institute \\ of Excellence on Tissue Engineering and Regenerative Medicine, AvePark, S. Cláudio de Barco, Taipas 4806-909, \\ Guimarães, Portugal \\ ${ }^{2}$ IBB - Institute for Biotechnology and Bioengineering, PT Government Associated Laboratory, Guimarães, Portugal \\ ${ }^{3}$ Facultad de Ciencias de la Salud, Dep. de Fisiología, Farmacología y Toxicología Universidad CEU - Cardenal Herrera \\ Edificio Seminario s/n. 46113 Moncada, Valencia, Spain \\ ${ }^{4}$ Center for Biomaterials and Tissue Engineering, Universidad Politécnica de Valencia, Camino de Vera s/n, \\ Valencia E-46022, Spain \\ ${ }^{5}$ CIBER en Bioingeniería, Biomateriales y Nanomedicina, Valencia, Spain \\ ${ }^{6}$ Centro de Investigación Príncipe Felipe, Regenerative Medicine Unit, Autopista del Saler 16, Valencia E-46013, Spain
}

Received 4 February 2009; revised 2 October 2009; accepted 16 December 2009

Published online 24 March 2010 in Wiley InterScience (www.interscience.wiley.com). DOI: 10.1002/jbm.a.32753

\begin{abstract}
Poly(L-lactic acid), PLLA, a synthetic biodegradable polyester, is widely accepted in tissue engineering. Hyaluronic acid (HA), a natural polymer, exhibits an excellent biocompatibility, influences cell signaling, proliferation, and differentiation. In this study, HA crosslinking was performed by immersion of the polysaccharide in water-acetone mixtures containing glutaraldehyde (GA). The objective of this work is to produce PLLA scaffolds with the pores coated with HA, that could be beneficial for bone tissue engineering applications. PLLA tridimensional scaffolds were prepared by compression molding followed by salt leaching. After the scaffolds impregnation with soluble HA solutions of distinct concentration, a GA-crosslinking reaction followed by inactivation of the unreacted GA with glycine was carried out. An increase on surface roughness is shown by scanning electron microscopy (SEM) with the addi-
\end{abstract}

tion of HA. Toluidine blue staining indicates the present of stable crosslinked HA. An estimation of the HA original weight in the hybrid scaffolds was performed using thermal gravimetric analyses. FTIR-ATR and XPS confirmed the crosslinking reaction. Preliminary in vitro cell culture studies were carried out using a mouse lung fibroblast cell line (L929). SEM micrographs of L929 showed that cells adhered well, spread actively throughout all scaffolds, and grew favorably. A MTS test indicated that cells were viable when cultured onto the surface of all scaffolds, suggesting that the introduction of crosslinked HA did not increase the cytotoxicity of the hybrid scaffolds. () 2010 Wiley Periodicals, Inc. J Biomed Mater Res Part A: 94A: 856-869, 2010

Key Words: poly(L-lactic acid), hyaluronic acid, hybrid constructs, tissue engineering, cytotoxicity

\section{INTRODUCTION}

Bone is a dynamic and highly vascularized tissue that continues to remodel throughout the lifetime of an individual. The self-healing capacity of bone is widely used for the repair of small fractures. However, bone grafts are needed to provide support, fill lacunae, and enhance biological repair when the skeletal defect reaches a critical size. ${ }^{1-3}$

Tissue engineering (TE) emergence is boosted as an alternative potential solution to current methodologies for tissue transplantation and grafting. ${ }^{1,4}$ A key component in TE for bone regeneration is the scaffold that serves as a template for cell interactions and the formation of bone-extracellular matrix (ECM) to provide structural support to the newly formed tissue. ${ }^{5}$ The ideal scaffold should provide a suitable environment for tissue development. It should ex- hibit suitable biocompatibility, favor cell attachment, proliferation and differentiation, bone growth, and in vivo revascularization. In addition, it should support osteointegration with the host bone with an interconnected and highly porous structure, and the gradual replacement of the scaffold by newly formed bone. ${ }^{2,5}$ It should also be adaptable to an irregular wound site and/or support mechanical loading, with mechanical properties matching those of the target tissue. Finally, it should be sterilizable without loss of properties, storable and implantable, without any detrimental effects on surrounding tissue. ${ }^{2,6}$ Some authors argue that the scaffold should be also designed to mimic the native ECM environment as much as possible. ${ }^{6}$

Synthetic biodegradable polyesters, such as poly(L-lactide) (PLLA), are widely accepted in TE. ${ }^{7-10}$ Although these

Correspondence to: J. F. Mano; e-mail: jmano@dep.uminho.pt

Contract grant sponsor: Portuguese Foundation for Science and Technology (FCT) through POCTI

Contract grant sponsor: FEDER programs including project ProteoLight; contract grant number: PTDC/FIS/68517/2006

Contract grant sponsor: European Union funded STREP Project HIPPOCRATES; contract grant number: NMP3-CT-2003-505758

Contract grant sponsor: European NoE EXPERTISSUES; contract grant number: NMP3-CT-2004-500283

Contract grant sponsor: Spanish Ministry of Science (The FEDER financial support); contract grant number: MAT2007-66759-C03-01 
materials revealed good mechanical properties, high purity, and molecular control, convenient processing and favorable degradation rate that match the rate of healing of damaged tissue, ${ }^{6}$ the major drawback is its hydrophobic nature and acidic degradation products. ${ }^{10-13}$ PLLA, however, does not possess the necessary specific bioactive abilities to accelerate the ECM secretion and regeneration of cultured cells. ${ }^{14}$ In addition, because the PLLA do not have functional groups, other than end groups, enabling chemical modification to change its characteristics, much progress in biomedical applications could be achieved if it were possible to retain its beneficial properties while incorporating functionalities promoting specific and desirable biological interactions. ${ }^{8,14,15}$ Many strategies have been adopted, including a change of the surface charge, ${ }^{16}$ increase in the surface roughness ${ }^{17}$ and hydrophilicity, ${ }^{18}$ or the immobilization of a biocompatible layer on the surface. ${ }^{19}$ Another approach involves the use of natural polymers as scaffolds, since they may promote cell adhesion due to having specific active sites, however, associated with poor mechanical properties and high rates of degradation. ${ }^{5,13}$ Therefore, scaffolds with the features of both natural polymers and polyesters may be desirable and will be advantageous if they match in certain extent those of the target tissue's ECM. ${ }^{4,6,7,20,21}$

The use of natural materials, such as hyaluronic acid (HA), in the production of scaffolds, can impart intrinsic signals within the structure that can enhance tissue formation. ${ }^{4,22} \mathrm{HA}$ is a negatively charged, heavily hydrated linear and natural occurring glycosaminoglycan, composed of $\beta$ 1,4-linked D-glucuronic acid( $\beta$-1,3)- $N$-acetyl-D-glucosamine disaccharide units with a molecular size of $0.1-10 \mathrm{MDa}^{23,24}$ In its native state, $\mathrm{HA}$ is a high molecular weight polymer in the ECM of almost all animal tissues. ${ }^{25}$ Thus, HA is considered as a space-filling, structure-stabilizing, cell coating, and cell protective polysaccharide. ${ }^{25-27} \mathrm{HA}$ has been shown to have important functions in providing hydration in the ECM, and vitally regulating embryonic development, tissue organization, wound healing, and angiogenesis, being also involved in cell signaling, growth, and differentiation. ${ }^{24,26,28,29}$ In addition, it has been shown that HA exhibits excellent biocompatibility, is non-thrombogenic, non-immunogenic, and does not induce chronic inflammation. ${ }^{26,30,31}$ However, biomedical applications of HA have been hindered by its short residence time and lack of mechanical integrity in an aqueous environment. ${ }^{23,32}$ HA can, therefore, be chemically derivatized and crosslinked to generate biomaterials with diverse physicochemical and mechanical properties, ${ }^{26}$ typically involving the carboxylic acid groups and/or the hydroxyl groups of its backbone. ${ }^{22,32-34}$ Dialdehydes are believed to crosslink HA through formation of acetal or hemiacetal groups on neighboring chains, with kinetic and spectroscopic evidences indicating a prevalence of the hemiacetal. It is assumed that glutaraldehyde (GA) forms either a hemiacetal or an ether link with HA under acidic conditions. ${ }^{23,33}$ However, the use of GA is limited for applications that imply cell culture, as this crosslinking agent is recognized as toxic and often leads to cell death. ${ }^{35}$ Strategies have to be used to minimize that risk and inactivate any unreacted GA. ${ }^{36-39}$ Never- theless, due to the excess of HA over incorporated crosslinker amounts and the fact that biologically active functional groups are not involved in crosslinking, favorable biological properties of the parent $\mathrm{HA}$ chains can be retained. If we consider these properties and the added mechanical versatility of HA, this polysaccharide is an attractive biomaterial for effective tissue regeneration. ${ }^{26}$

In this study, tridimensional PLLA porous hybrid scaffolds were coated with HA, followed by crosslinking with $\mathrm{GA}$, to produce biomimetic porous scaffolds for cortical bone TE applications. Crosslinking was performed by immersion of HA in water-acetone mixtures containing GA, with increasing water/acetone ratios. PLLA tridimensional scaffolds were prepared by compression molding followed by salt leaching method. After the scaffolds impregnation with soluble HA solutions of increasing concentration, a GAcrosslinking reaction was carried out. To reduce the cytotoxicity possibly induced by the GA, the materials were immersed in a glycine aqueous solution to inactivate any unreacted GA. The GA-crosslinking reaction was confirmed by Fourier transform infrared total reflectance spectroscopy (FTIR-ATR) and X-ray photoelectron spectroscopy (XPS) analyses. The morphological changes, deposition, and stability of the crosslinked HA were examined by scanning electron microscopy (SEM), toluidine blue (TB) staining, and thermal gravimetric analysis (TGA). In addition, mechanical properties were investigated for all scaffolds. PLLA scaffolds were further analyzed through gravimetry to investigate porosity. Preliminary in vitro cell culture studies were carried out using a mouse lung fibroblast cell line (L929). L929 were seeded onto the PLLA and hybrid scaffolds, and their adhesion was assessed by SEM. To screen possible cytotoxicity an MTS [3-(4,5-dimethylthiazol-2-yl)-5-(3-carboxymethoxyphenyl)-2-(4-sulfophenyl)-2H-tetrazolium] assay was performed after $72 \mathrm{~h}$ of in vitro culturing. L929 morphology and proliferation were also qualitatively evaluated by SEM after $72 \mathrm{~h}$ of in vitro culturing.

\section{MATERIALS AND METHODS \\ Materials}

In this study, a commercial grade poly(L-lactic acid) (PLLA) of high stereoregularity (Cargill Dow Polymer $M_{\mathrm{n}}$ : 69,000, $\left.M_{\mathrm{w}} / M_{\mathrm{n}}: 1.734\right)$ was used. Hyaluronic acid sodium salt (HA), from Streptococcus equi, supplied as dry powder $\left(M_{\mathrm{w}}: 1.63\right.$ MDa, Fluka). GA, Glycine, Toluidine Blue 0, $\alpha$-MEM medium, sodium bicarbonate $\left(\mathrm{NaHCO}_{3}\right)$, and sterile phosphate buffer saline (PBS) solution were purchased from Sigma-Aldrich. Hydrochloric acid ( $\mathrm{HCl}$ ) and ethanol were purchased from Panreac (Portugal) and acetone obtained from Pronolab (Portugal). Fetal bovine serum (FBS), antibiotic-antimycotic solution (A/B) consisting of $100 \mathrm{U} / \mathrm{mL}$ penicillin $\mathrm{G}$ sodium, $100 \mu \mathrm{g} / \mathrm{mL}$ streptomycin sulfate, and $250 \mathrm{ng} / \mathrm{mL}$ amphotericin B (as Fungizone), sterile magnesium chloride-free phosphate buffered saline (PBS) solution, and ethylenediaminetetraacetic acid (EDTA) were purchased from GibcoInvitrogen. Mouse lung fibroblast cell line (L929) was purchased from HPA culture collections. MTS [3-(4,5-dimethylthiazol-2-yl)-5-(3-carboxymethoxyphenyl)-2-(4-sulfophenyl)- 
2H-tetrazolium] was obtained from VWR. Finally, hexamethyldisilazane (HMDS), a chemical dryer, was purchased from Electron Microscopy Sciences.

\section{Processing methodologies}

Solvent casting. To confirm the chemical crosslinking reaction, 1\% HA films were prepared by solvent casting, as previously reported by Collins and Birkinshaw ${ }^{23}$ and Tomihata and Ikada ${ }^{33}$ and afterward analyzed by Fourier transform infrared total reflectance spectroscopy (FTIR-ATR) and X-ray photoelectron spectroscopy (XPS). This methodology enabled to study the crosslinking reaction without the synthetic polymer interference.

Compression molding followed by salt leaching. In this study, tridimensional PLLA cubical scaffolds were prepared by compression molding followed by salt leaching, as described elsewhere. ${ }^{11,40,41}$

A schematic representation of the scaffolds processing route used in this study can be seen in Figure 1.

Powder preparation and compounding. The PLLA granules were milled using an IKA mill (IKA, UNIVERSALMÜHLE M20) with liquid nitrogen until obtaining a powder. The PLLA with a particle size below $500 \mu \mathrm{m}$ were then blended with the sodium chloride $(\mathrm{NaCl})$ particles $\left(\rho=2.17 \mathrm{~g} / \mathrm{cm}^{3}\right)$ with sizes in the range of 500-1000 $\mu \mathrm{m}$. It was used a 4:1 $\mathrm{NaCl} /$ PLLA (w/w) ratio for each disc prepared.

The compression molding followed by particle leaching method was based on blending together PLLA and the leachable particles, in sufficient amounts to provide a continuous phase of the polymer and a dispersed phase of leachable particles in the blend.

\section{Scaffold production}

To fabricate the individual components, the blend was compress molded in a steel cylindrical mold $(60 \mathrm{~mm}$ diameter and $10 \mathrm{~mm}$ height), using a Moore hydraulic press with $5 \times$ $10^{4} \mathrm{~kg}$ capacity. To prevent PLLA adhesion to the hot plates, teflon membranes were used. Then, the blend was compressed for exactly $7 \mathrm{~min}$, at top and bottom platen temperature of $180^{\circ} \mathrm{C}$. To remove the trapped air bubbles, the pressure was slowly raised to $1 \times 10^{4} \mathrm{~kg}$ and released, and this process was repeated for five times. After that, the mold was immediately cooled and the discs were removed from the mold.

\section{Leaching}

The molded discs were cut to obtain cubes with $4.5 \times 4.5$ $\times 4.5 \mathrm{~mm}^{3}$. The cubes were immersed in distilled water, which was changed every $4 \mathrm{~h}$, for the period of $1 \mathrm{w}$ to remove all the salt particles. Finally, scaffolds were dried for $4 \mathrm{~h}$ at room temperature and placed overnight in a vacuum woven, at $40^{\circ} \mathrm{C}$, to completely remove the water.

\section{HA coating and crosslinking}

$\boldsymbol{H A}$ coating. Soluble and homogenous $0.05,0.1,0.5$, and $1 \%$ HA solutions, respectively, were prepared by sieving the HA

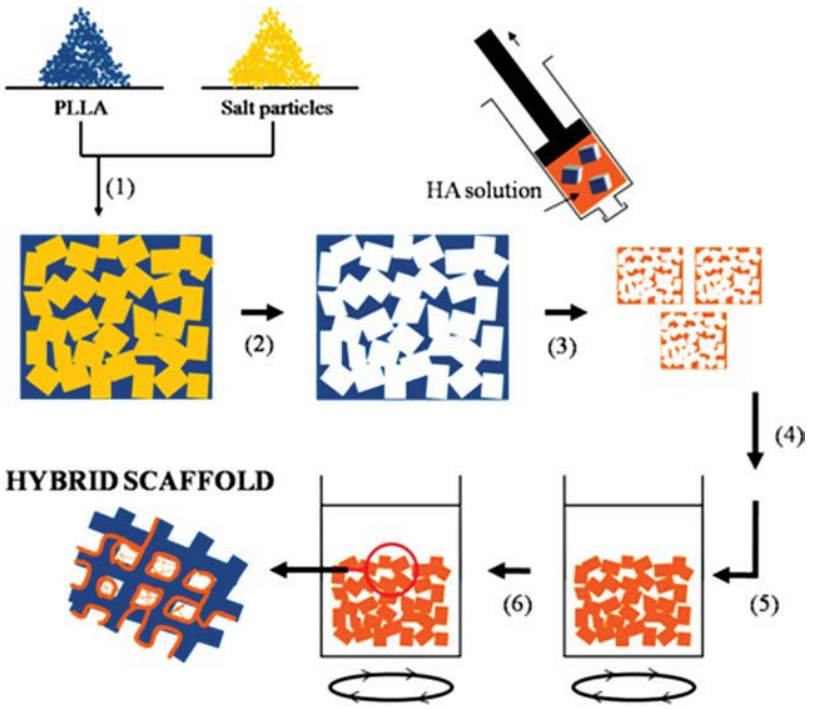

FIGURE 1. Schematic representation of the processing methodology used to obtain the PLLA/HAx hybrid scaffolds: (1) Compounding and compression molding, (2) Salt leaching, (3) Impregnation of HA solutions of different concentrations $(0.05,0.1,0.5$, and $1 \%)$, induced by vacuum, (4) Vacuum drying, (5) Crosslinking solutions with acetone, water, $\mathrm{HCl}$, and glutaraldehyde, and (6) Washing and vacuum drying. [Color figure can be viewed in the online issue, which is available at www.interscience.wiley.com.]

particles into milli-Q water, to expose the maximum area for solvent interaction. This was followed by agitation, to minimize shear stress and to achieve solutions with uniform viscosity, at room temperature, for up to 4 days. On the basis of a previous impregnation method to generate PLLA-based hybrid scaffolds, ${ }^{20,21}$ the PLLA scaffolds were immersed into each HA solution, using a vacuum accessory, followed by drying overnight, at room temperature and under vacuum.

HA crosslinking. The HA modification was performed through HA crosslinking with GA. ${ }^{23,33}$ The HA crosslinking was performed as follows: (1) immersion of PLLA scaffold in $10 \mathrm{~mL}$ of a solution containing acetone-milli-Q water 80:20 (V/V), $0.01 M \mathrm{HCl}$ and $250 \mathrm{mM} \mathrm{GA}$, for $48 \mathrm{~h}$, at room temperature and under continuous agitation. The acetone prevents the dissolution of the HA into the reaction solution, and all the reaction vessels were sealed to prevent evaporation of the acetone. The acetone concentration of $80 \%(\mathrm{~V} / \mathrm{V}$ ) and crosslinker molarity was based on previously published data. ${ }^{23,33}$ With GA, crosslinking is favored by acidic conditions, thus $0.01 \mathrm{M} \mathrm{HCl}$ was used as $\mathrm{pH}$ adjuster and catalyst; (2) immersion of the scaffold in a similar solution except containing acetone-water 50:50, for $48 \mathrm{~h}$ and under continuous agitation; (3) after reaction, the scaffolds were thoroughly washed by immersion in an ethanol-water 50:50 (V/V) solution ${ }^{23,33}$; and (4) the scaffolds were subsequently immersed in a blocking agent $(0.025 \mathrm{M}$ glycine aqueous solution) for $1 \mathrm{~h}$ to inactivate any unreacted $\mathrm{GA}^{36,38,39}$

\section{Characterization of the PLLA/HAx scaffolds}

The final samples for characterization tests were: 1\% HA films (before and after crosslinking reaction), PLLA 
scaffolds, hybrid PLLA scaffolds coated with a HA 0.05, 0.1, 0.5 , and $1 \%$ solution followed by crosslinking (PLLA/ 0.05HAx, PLLA/0.1HAx, PLLA/0.5HAx, and PLLA/1HAx, respectively).

Before cell culture assays, all scaffolds were sterilized under ethylene oxide (EtO) atmosphere.

Morphology and porosity. The morphology of the samples, surface, and cross section, was analyzed using a Leica Cambridge S-360 scanning electron microscope (SEM) (Leica Cambridge), at an accelerating voltage of $15 \mathrm{kV}$ at different magnifications. All specimens were pre-coated with a conductive layer of sputtered gold.

The volume fraction of pores in the PLLA scaffolds, porosity, was measured using gravimetric method. The samples were dried, weighted, filled with ethanol using a vacuum accessory, and subsequently weighted. The ethanol was selected so that it wouldn't swallow or degrade the scaffolds' material. Porosity was determined as a function of the volume of pores and the total volume of the scaffold using Eq. (1). The volume occupied by pores, $V_{\text {pore, }}$ was deduced from the weight difference between dry $\left(m_{\text {dry }}\right)$ and wet $\left(m_{\text {wet }}\right)$ sample [Eq. (2)]. Thus, the volume of pores equals the volume occupied by the absorbed ethanol:

$$
\text { Porosity, } p=V_{\text {pores }} / V_{\text {total }}=V_{\text {pores }} /\left(V_{\text {scaffold }}+V_{\text {pores }}\right)
$$

in which $V_{\text {pores }}$ and $V_{\text {scaffold }}$ are determined as:

$$
V_{\text {pores }}=\left(m_{\text {wet }}-m_{\text {dry }}\right) / d_{\text {ethanol }}, V_{\text {scaffold }}=m_{\text {dry }} / d_{\text {PLLA }}
$$

where $d_{\text {ethanol }}$ is the density of ethanol, equal to $0.79 \mathrm{~g} / \mathrm{cm}^{3}$ and $d_{\text {PLLA }}$ is the density of the scaffolds' material, PLLA, equal to $1.25 \mathrm{~g} / \mathrm{cm}^{3}$. 42,43

For each sample, at least three measurements were carried out and the obtained values were averaged.

\section{HA crosslinking reaction: Qualitative and quantitative analyses}

Stereomicroscopy: Toluidine blue staining. The different scaffolds were immersed in a $1 \%$ TB solution for $3 \mathrm{~min}$, and then thoroughly washed with distilled water. Two different analyses were performed: (1) to the different scaffolds after the crosslinking reaction and washing procedure; and (2) to the different scaffolds after the crosslinking reaction, washing procedure, and subsequent 14 days of immersion in distilled water. Stereomicroscopy images were taken from the surface of the different scaffolds, at magnitudes of $5 \times$ and $6.4 \times$, using a Stereomicroscope (Zeiss Stemi 1000 PG-HITEC).

Thermal gravimetric analysis. Thermal gravimetric analyses (TGA Q500 V6.5 Build 196) were made to HAx, PLLA, PLLA/0.05HAx, PLLA/0.1HAx, PLLA/0.5HAx, and PLLA/ $1 \mathrm{HAx}$ samples. Samples were placed on the balance and the temperature was raised from 30 to $1000^{\circ} \mathrm{C}$, at a heating rate of $20^{\circ} \mathrm{C} / \mathrm{min}$. The balance purge flow was of $40 \mathrm{~mL} /$ min and sample purge flow, of liquid nitrogen, was of
$60 \mathrm{~mL} / \mathrm{min}$. The mass of the sample pan was continuously monitored as a function of temperature.

Fourier transform infrared total reflectance spectroscopy. The crosslinking reaction was investigated by FTIR-ATR in the 1\% HA and HAx films. The infrared spectra was recorded on a spectrophotometer (IR-Prestige-21, Shimadzu, Japan), controlled by IRsolution software. The spectra were averaged on 32 scans in the range of $600-4400 \mathrm{~cm}^{-1}$ with a resolution of $4 \mathrm{~cm}^{-1}$.

$X$-ray photoelectron spectroscopy. The XPS analyses to the $1 \%$ HA and HAx films were performed using a VG Escalab 250 iXL ESCA instrument (VG Scientific) equipped with a monochromatic $\mathrm{Al}(\mathrm{K} \alpha)$ X-ray source operating at 1486.92 $\mathrm{eV}$. Because of the non conductive nature of the samples it was necessary to use an electron flood gun to minimize surface charging. Neutralization of the surface charge was performed using both a low energy flood gun (electrons in the range of $0-14 \mathrm{eV}$ ) and an electrically grounded stain steel screen placed directly on the sample surface. The measurements were carried out at a take-off angle of $90^{\circ}$ (normal to the surface). The measurement was performed in a Constant Analyzer Energy mode (CAE) with $100 \mathrm{eV}$ pass energy for survey spectra and $20 \mathrm{eV}$ pass energy for high resolution spectra. Using the standard Scofield photoemission cross sections, surface elemental composition was determined. Overlapping peaks were resolved into their individual components by XPSPEAK 4.1 software.

Mechanical analysis: Compression test. Uniaxial compression tests were performed on cubic scaffolds using a Universal tensile testing machine (Instron 5540 Universal Machine) with a $1 \mathrm{kN}$ load cell. Cubical scaffolds ( $\sim 5 \mathrm{~mm}$ of edge) were compressed at room temperature using a crosshead speed of $2 \mathrm{~mm} / \mathrm{min}$. The test was stop when $60 \%$ of strain was reached. The values reported are the average of at least five specimens per condition. The compressive modulus was determined in the most linear region of the stress-strain graph. A two-tailed, two-sample Student's $t$ test assuming unequal variances was performed to the results.

\section{In vitro cell culture studies}

To assess the effect of the different crosslinked HA coatings, especially the result of the use of GA as a crosslinking agent, a MTS [3-(4,5-dimethylthiazol-2-yl)-5-(3-carboxymethoxyphenyl)-2-(4-sulfophenyl)-2H-tetrazolium] preliminary cytotoxicity assay was performed. Cell adhesion, morphology, and proliferation were also assessed by SEM, after 24 and $72 \mathrm{~h}$. For the present studies, mouse lung fibroblast cell line (L929) was selected for use in the cell culture studies.

L929 culturing/expansion and seeding. L929 were replated into a T150 $\mathrm{cm}^{2}$ culture flask and then expanded in the presence of $\alpha$-MEM medium with $10 \%$ FBS and $1 \%$ $\mathrm{A} / \mathrm{B}$, at $37^{\circ} \mathrm{C}$ in a $5 \% \mathrm{CO}_{2}$ incubator. After reaching confluency, the cells (passage 12 and 13, P12 and P13) were 
released from substratum with $0.05 \%$ tripsin-0.53 $\mathrm{mM}$ EDTA and centrifuged at $900 \mathrm{rpm}$ for $10 \mathrm{~min}$. Cells were resuspended in culture media, counted and $2 \times 10^{4}$ and $1 \times 10^{5}$ cell suspensions prepared (P13, P14). The culture medium was changed every 2 days for removal of nonadherent cells.

Before L929 seeding, all scaffolds were pretreated (deairation) to remove air bubble from the pores. Scaffolds were placed in $10 \mathrm{~mL}$ polystyrene tubes with ventilation cap. Culture media was added and scaffolds were deaired under vacuum using a $60 \mathrm{~mL}$ syringe with an attached 18G needle. ${ }^{44}$ Then, each scaffold was transferred into the respective well of a non-treated 24-well tissue culture polystyrene (TCPS, Greiner Bio-One) plate.

After expansion, L929 (P13 and P14) were seeded onto the surface of the scaffolds (PLLA, PLLA/0.05HAx, PLLA/ 0.1HAx, PLLA/0.5HAx, and PLLA/1HAx), in a drop wise manner, at the cell densities of $2 \times 10^{4}$ and $1 \times 10^{5}$ cells/ scaffold and cultured in $\alpha$-MEM medium under static conditions, for 24 and $72 \mathrm{~h}$. Culture media were changed after 2 days and triplicates of each type of scaffold were used. A TCPS control, for each cell concentration and time of culture were used.

L929 adhesion, morphology, and assessment of cytotoxicity. L929 adhesion and morphology were also investigated by scanning electron microscopy (SEM) analysis, after 24 and $72 \mathrm{~h}$ of culturing, for the seeding cell density of $1 \times$ $10^{5}$ cells/scaffold. For this purpose, after each culturing period, samples were removed from culture, carefully washed in $\mathrm{Mg} / \mathrm{Ca}$ free PBS solution, fixed with a $2.5 \%$ glutaraldehyde solution in the PBS and rinsed two times with the PBS. Afterwards, the samples were dehydrated in a series of ethanol concentrations $(40,50,60,70,80,90$, and $100 \%)$ and chemically dried with hexamethyldisilazane (HMDS). The samples were then sputter coated with gold before SEM observation.

The cytotoxicity of the different scaffolds was determined by carrying out an MTS [3-(4,5-dimethylthiazol-2-yl)5-(3-carboxymethoxyphenyl)-2-(4-sulfophenyl)-2H-tetrazolium] assay, directly on the scaffolds, after $72 \mathrm{~h}$, using a L929 cell line, for the seeding cell densities of $2 \times 10^{4}$ and $1 \times 10^{5}$ cells/scaffold. For this purpose, scaffold/ L929 cells constructs were transferred into a 24-well plate and washed with sterile PBS. Culture medium without FBS and without phenol red was mixed with MTS in a $5: 1$ ratio, added to the wells, until totally cover the constructs, and incubated for $3 \mathrm{~h}$ at $37^{\circ} \mathrm{C}$ in a $5 \% \mathrm{CO}_{2}$ incubator. After the incubation period, $100 \mathrm{~mL}$ of the MTS and medium mixture were transferred into each well of a 96well TCPS plate and absorbance was read at $490 \mathrm{~nm} .{ }^{45} \mathrm{~A}$ two-tailed, two-sample Student's $t$-test assuming unequal variances was performed to the results.

\section{RESULTS AND DISCUSSION Morphology and porosity}

Several manufacturing techniques have been developed to produce porous structures aimed at being used in $\mathrm{TE}^{7,13}$
Many of such methods use organic solvents that may lead to residual harmful substances upon processing for the transplanted cells or nearby tissues. ${ }^{41}$ In this work, the scaffolds were produced by compression molding followed by particulate leaching in aqueous medium. Such method was previously described by Lee et al., ${ }^{46}$ and is adequate to produce a porous structure without the use of organic solvent. This process is a straightforward, convenient method of fabricating porous scaffolds. As represented in Figure 2, it only requires PLLA and $\mathrm{NaCl}$ particles, and a compressing apparatus for achieving the correct PLLA-NaCl composite structure at an adequate temperature for connecting the PLLA particles without degrading them. ${ }^{46}$ The compression molding, particle leaching technique, gives rise to structures consisting in an open network of pores throughout the sample, which is very important for cell seeding and in-growth. ${ }^{41}$ With this technique, it is possible to control the percentage of porosity and the pore size by varying the amount and size of the leachable particles. ${ }^{41,47}$

For TE applications, it is important to ensure that the scaffold has an adequate architecture to balance the integrity, nutrient, and growth factor supply and cellular invasion. ${ }^{47,48}$ This balance is regulated by the pore size, porosity, and pore orientation within the scaffold. ${ }^{48}$ From Figure 2 , it can be observed that the PLLA scaffolds morphology it is as expected taking into consideration the size of the $\mathrm{NaCl}$ particles used. Moreover, some interconnectivity is observed indicating that the amount of $\mathrm{NaCl}$ particles used was adequate. Note that one could increase the interconnectivity of such scaffolds by using a second porogen. ${ }^{11}$ In fact, interconnected pores are necessary for bone tissue formation as a mean to mimic the bone trabecular structure, and because they allow cell migration and proliferation, as well as vascularization. ${ }^{5}$

The porosity of the PLLA scaffolds, determined by gravimetry, is of $68 \% \pm 5 \%$. However, the porosity of the scaffolds can be further augmented as desired with the addition of higher fraction of salt. On the other hand, the size of the scaffolds' pores could be altered by changing the size of the leachable particles. For that, it is important to consider the following premises: (1) in general, the compromise in mechanical properties of the scaffold with increasing porosity sets an upper limit in terms of how much porosity and the pore size that can be tolerated ${ }^{5}$ and (2) the microporosity (pores $<10 \mu \mathrm{m}$ ) contributes to the biological (cell-material interactions) and physicochemical properties (resorption and mechanical resilience) of the material. The macropores (pores $>50 \mu \mathrm{m}$ ) should also be interconnected to allow cell penetration into deeper layers, vascular invasion, and matrix dissolution. The estimated optimal sizes are in the range of $150-500 \mu \mathrm{m}$ for macropores ${ }^{4}$ and $>40$ $\mu \mathrm{m}$ for macropore interconnections. ${ }^{2,5,48}$ However, it is well accepted that for bone TE purposes pore size should be within the 200-900 $\mu \mathrm{m}$ range. ${ }^{10}$

SEM micrographs on PLLA and PLLA/HAx hybrid scaffolds surface also showed an obvious difference in surface morphology (Fig. 2). Similar textures are observed in the scaffolds cross section (data not shown). This topography 


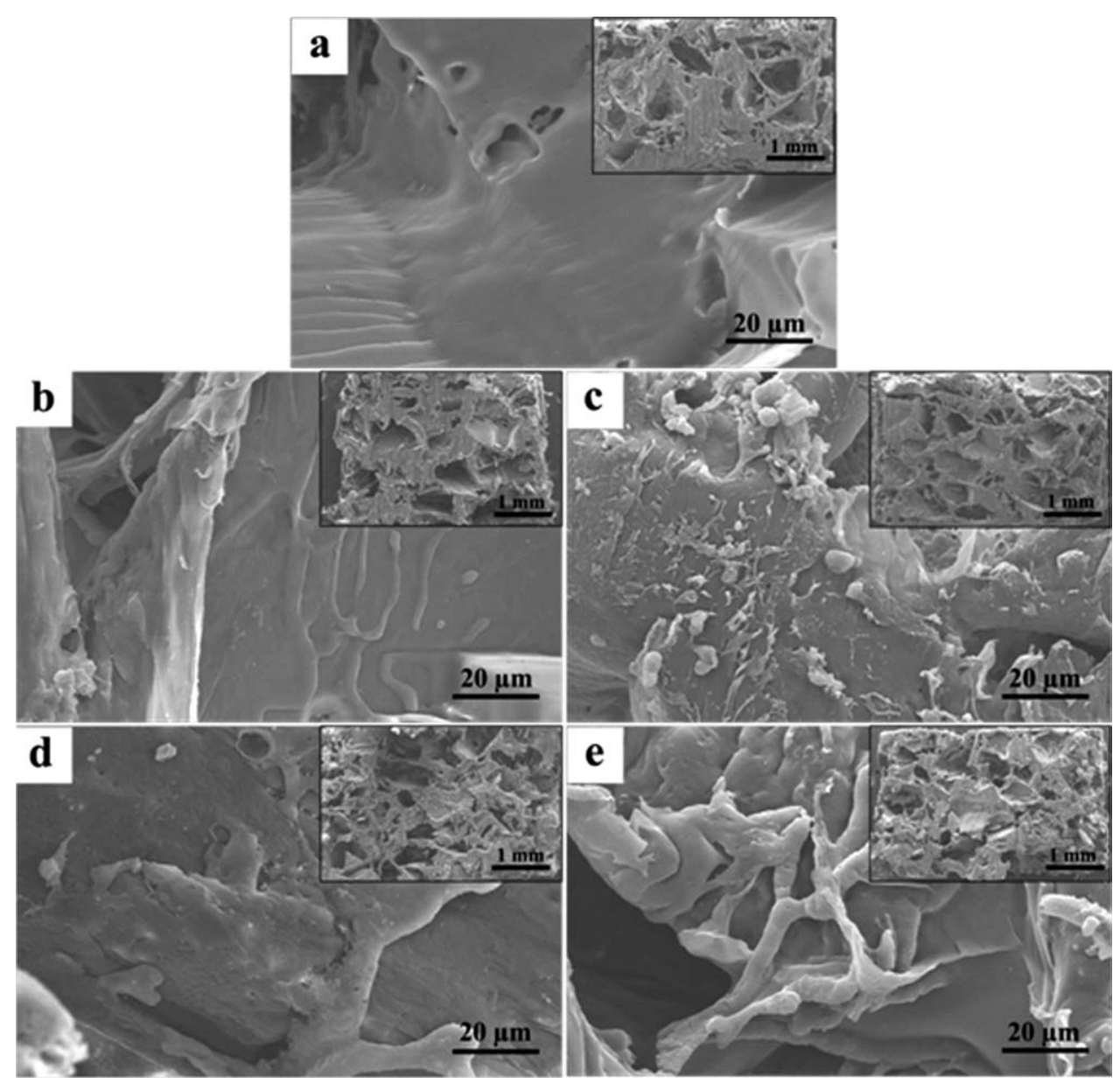

FIGURE 2. SEM micrographs of the surface of the developed scaffolds. (a) PLLA, (b) PLLA/0.05HAx, (c) PLLA/0.1HAx, (d) PLLA/0.5HAx, and (e) PLLA/1HAx. In the inserted low magnified images it is possible to have a better overall perspective of the pore sizes and interconnectivity of the scaffolds.

change was attributed to the following: when HA and GA complex solution was added to the PLLA scaffolds surface, precipitation can occur, resulting in HAx coatings. The HAx coating is not homogeneous but the polysaccharide fraction seems to be organized into extended structures onto the surface of the pores of the PLLA scaffold, increasing its roughness [Fig. 2(b-e)], although without pore obstructions. ${ }^{6,49,50}$ Surface roughness is expected to enhance attachment, proliferation, and differentiation of anchorage dependent bone forming cells. ${ }^{5}$

\section{HA crosslinking reaction: Qualitative and quantitative analyses}

Stereomicroscopy: Toluidine blue staining. TB dye form complexes with anionic glycoconjugates, such as proteoglycans and glycosaminoglycans, and constitute a way to identify such macromolecules. ${ }^{51,52}$ The presence of HA in the PLLA scaffolds was investigated by performing a TB staining. The TB stain qualitatively proves if after the crosslinking reaction and washing procedure, the HA remains in the scaffolds. Moreover, the stability of the HAx coating was investigated by immersing the scaffolds in water for 14 days, after the crosslinking reaction, followed by a washing procedure, and subsequent analysis of the presence of HA in the PLLA scaffolds. Figure 3(a) depicts stereomicroscopy images of the surface of the PLLA scaffolds after 0 days, that is, after the crosslinking reaction and washing procedure, where no staining is observed. It is also possible to observe the stereomicroscopy images of the surface of the PLLA/HAx scaffolds [Fig. 3(b-e)], after the crosslinking reaction, washing procedure and subsequent immersion of the scaffolds in water, for 14 days, where the staining seems to increase with the increase of HA content. The inserted images illustrate stereomicroscopy images of the surface of the PLLA/HAx scaffolds after 0 days. The simple HA coating is not eliminated through immersion in water, and therefore, it is a good indication of the success of the crosslinking reaction.

Thermal gravimetric analysis. Thermogravimetric analysis was performed to all types of materials in study: $\mathrm{HAx}$, PLLA, PLLA/0.05HAx, PLLA/0.1HAx, PLLA/0.5HAx, and PLLA/1HAx, to determine changes in weight as a function of temperature. GA replaces part of the hydroxyl groups, and the crosslinking causes a change in the polymer 


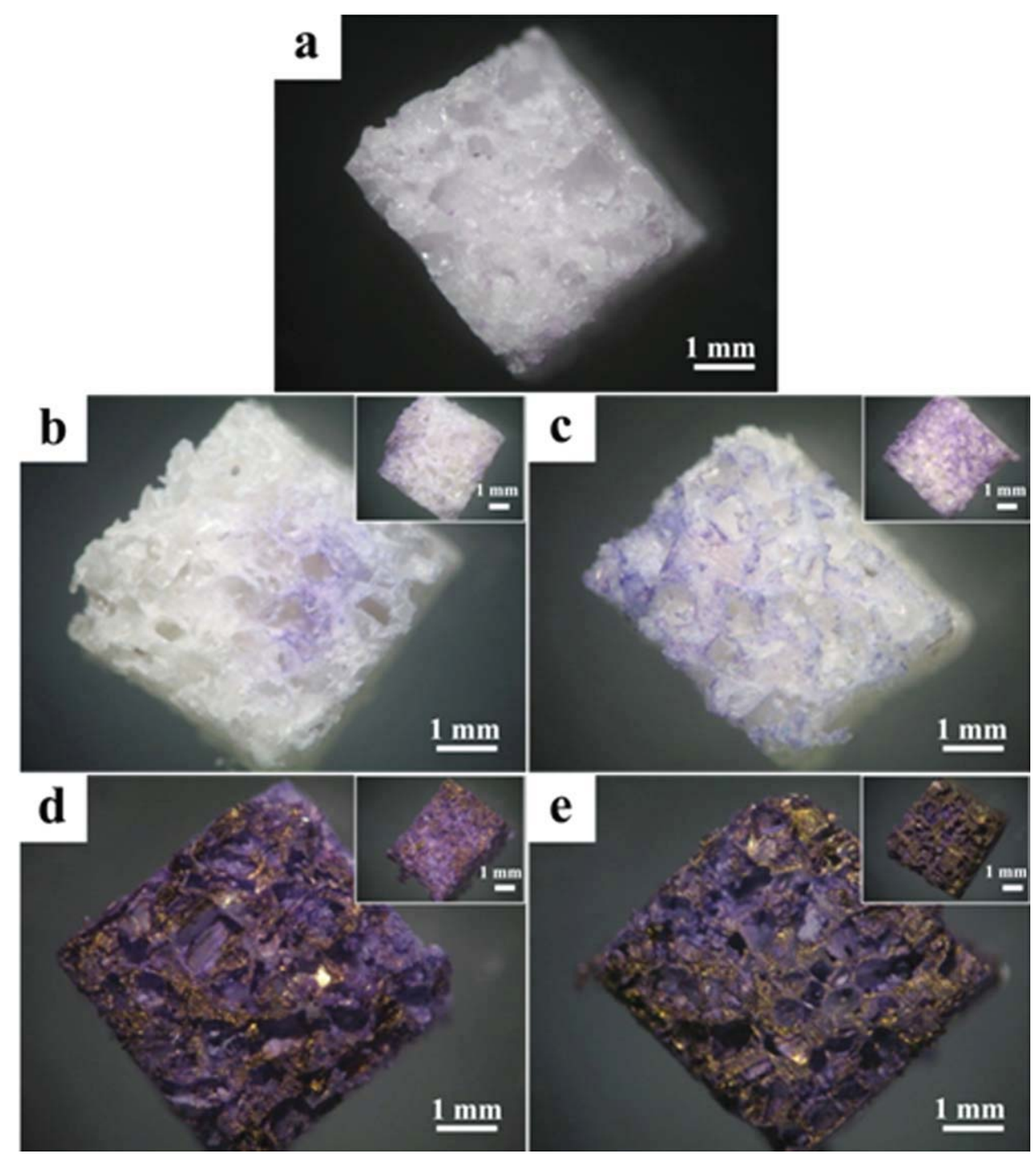

FIGURE 3. Stereomicroscopy images of the surface of the developed scaffolds after immersion on a TB dye: (a) PLLA, 0 days, (b) PLLA/0.05HAx, 14 days, (c) PLLA/0.1HAx, 14 days, (d) PLLA/0.5HAx, 14 days, and (e) PLLA/1HAx, 14 days. The inserted images were taken after 0 days, respectively. [Color figure can be viewed in the online issue, which is available at www.interscience.wiley.com.]

structure. These physicochemical changes are reflected in the thermal behavior of the distinct materials. ${ }^{53,54}$

Figure 4 represents part of the TGA scan of all the materials in study. The differences between the distinct materials are clearly shown, and an analysis was done for the particular temperature of $600^{\circ} \mathrm{C}$. Between $800^{\circ} \mathrm{C}$ and $1000^{\circ} \mathrm{C}$, it is possible to observe a progressive weight decrease due to that residual HA. This result is a good evidence that the residual weight at $600^{\circ} \mathrm{C}$ is $\mathrm{HA}$.

On the basis of the TGA results, an estimation of the HAx original weight in the hybrid scaffolds was performed through the following rationale: at $600^{\circ} \mathrm{C}, 30 \%$ of the original HAx remains in the HAx sample and the residual weight of the PLLA sample is negligible. At $600^{\circ} \mathrm{C}$, if the residual weight of the hybrid sample is $w_{\mathrm{p}}$ the original HA mass on the referred scaffolds is $w_{\mathrm{r}} / 0.3$. Table I shows determined values. As expected, the content of $\mathrm{HA}$ in the scaffold increases with the HA concentration of the solution used to impregnate the PLLA scaffolds.

Fourier transform infrared total reflectance spectroscopy. IR spectroscopy measurements were performed on 1\% HA films, before and after crosslinking reaction (Fig. 5), to identify the bonds responsible for the HA crosslinking with GA.

By analyzing the FTIR spectra of Figure 5(a), it is possible to observe a characteristic peak of the HA sodium salt: the $-\mathrm{OH}$ and $-\mathrm{NH}$ bond stretching (st) vibration at 2993$3716 \mathrm{~cm}^{-1}$, derived from the hydroxyl and secondary carboxylic acid amide bonds, respectively. It is also possible to observe the $\mathrm{C}=0$ (st) of carbonyl groups at $1604 \mathrm{~cm}^{-1}$, symmetric (st) of carboxylate salts at $1410 \mathrm{~cm}^{-1}, \mathrm{C}-\mathrm{O}-\mathrm{C}$ (st) symmetric ester band at $1030 \mathrm{~cm}^{-1}$, the alkane $-\mathrm{CH}$ (st) bond at $2917 \mathrm{~cm}^{-1}$, and the HA aromatic groups at 


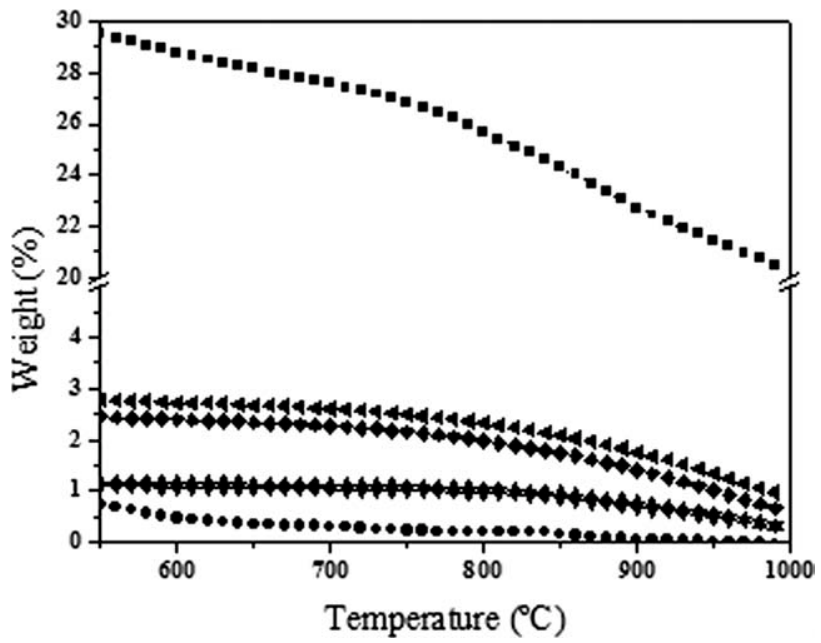

FIGURE 4. Detail of the thermogravimetry scans of the developed films and scaffolds, representing relative weight versus temperature. -ם $1 \%$ HAx, - - PLLA, - $\mathbf{\Delta}$ - PLLA/0.05HAx, - - PLLA/0.1HAx, PLLA/0.5HAx, and - 4 - PLLA/1HAx.

around $690 \mathrm{~cm}^{-1}{ }^{55,56}$ By comparing the FTIR-ATR results before and after crosslinking, it is possible to observe that no new bonds ascribed to HA crosslinking were detected [Fig. 5(b)]. ${ }^{33}$ Instead of formation of different bonds than the bonds already present in the $\mathrm{HA}$ molecules, the $\mathrm{C}-\mathrm{OH}$ bonds are replaced by $\mathrm{C}-\mathrm{O}-\mathrm{C}$ bonds. However, comparing the intensity of different peaks, the latter observation can be confirmed. First, it is crucial to consider that during the crosslinking reaction HA can solubilize in water, up to a certain extension, despite the presence of acetone. This explains why all peaks have lower intensities. Nevertheless, some observations can be performed: the $\mathrm{HCl}$ addition on FTIR-ATR spectra of the uncrosslinked HA film resulted in a clear decrease of the absorbance at $1600 \mathrm{~cm}^{-1}$, and an increase of the absorbance at $1730 \mathrm{~cm}^{-1}$ was observed. This change can be ascribed to the ion exchange of carboxyl groups of HA from $-\mathrm{COO}^{-} \mathrm{Na}^{+}$to $-\mathrm{COOH}(\mathrm{x})$ caused by the referred $\mathrm{HCl}$ addition. ${ }^{33}$ Moreover, the $-\mathrm{OH}$ (st) peak $(+)$, have a significant decrease.

It is already stated that ethanol inhibits crosslinking of HA with GA, which suggests that hydroxyl groups of HA are involved in the crosslinking reaction with GA, competing with hydroxyl groups of ethanol. ${ }^{33}$ If the agent has two aldehyde groups in one molecule like GA, the following crosslinks will be formed between the two polyol molecules, being also assumed that the HA crosslinking with GA gives rise to the formation of acetals. ${ }^{33}$

TABLE I. Estimation of HAx Original Weight in Each PLLA/HAx Scaffolds

\begin{tabular}{lcc}
\hline Scaffold & $\begin{array}{c}\text { Weight } \\
\left(\mathrm{mg}, T=600^{\circ} \mathrm{C}\right)\end{array}$ & $\begin{array}{c}\text { Estimated HAx } \\
\text { Original Weight }(\mathrm{mg})\end{array}$ \\
\hline PLLA/0.05HAx & 0.15 & 0.50 \\
PLLA/0.1HAx & 0.18 & 0.60 \\
PLLA/0.5HAx & 0.19 & 0.64 \\
PLLA/1HAx & 0.20 & 0.67 \\
\hline
\end{tabular}

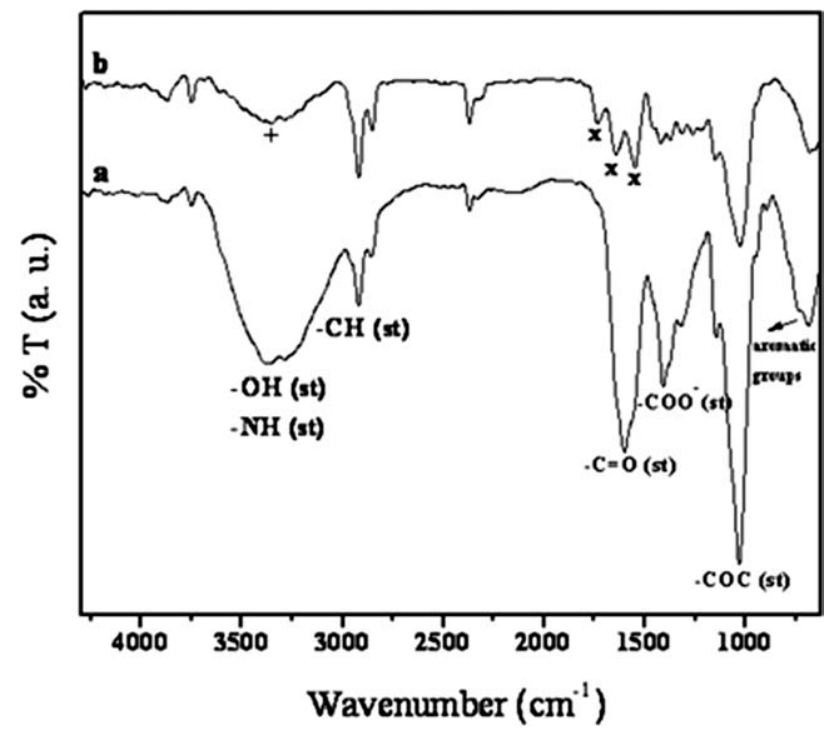

FIGURE 5. FTIR-ATR spectra of: (a) $1 \% \mathrm{HA}$ films and (b) $1 \% \mathrm{HAx}$ films.

X-ray photoelectron spectroscopy. To further verify the findings from the FTIR spectra, XPS analyses of 1\% HA and HAx films were performed. Table II shows the XPS atomic percentage of Carbon (C), Oxygen (O), and Sodium (Na) elements present in the referred samples, where it is observable an increase of the values for $\mathrm{C}$ content when crosslinking was performed. Trace elements were also detected.

Because no new elements were added to the HA structure besides the ones existing in the HA repeating units, the GA-crosslinking reaction can be assessed by XPS. As previously highlighted, the GA-crosslinking reaction seems to take place with the hydroxylic groups, with a replacement of the $\mathrm{C}-\mathrm{OH}$ by $\mathrm{C}-\mathrm{O}-\mathrm{C}$ groups. For that reason, and because hydrogen cannot be measured by XPS, ${ }^{57}$ the crosslinking reaction can be easily confirmed by observing the difference between the $\mathrm{C} 1 \mathrm{~s}(\mathrm{C}=0)$ and $\mathrm{C} 1 \mathrm{~s}(\mathrm{C}-\mathrm{O})$ peaks, with the $\mathrm{C} 1 \mathrm{~s}(\mathrm{C}-\mathrm{C}, \mathrm{C}-\mathrm{H})$ peak. Experimental results showed that XPS was an effective technique in detecting the subtle variation in atomic energy binding before and after crosslinking. Figure 6 shows the complex $\mathrm{C} 1 \mathrm{~s}$ bond for the two materials that was decomposed into Gaussian contributions, using a non-linear algorithm. The intensity of the individual peaks is shown in Table III. The intensity of the C1s $(\mathrm{C}-\mathrm{C}, \mathrm{C}-\mathrm{H})$ peak of the HAx spectra is higher for HAx. Moreover, it is observed a slight increase on peaks $2(\mathrm{C}-\mathrm{O})$ and $3(\mathrm{C}=0)$ and a large one on peak $1(\mathrm{C}-\mathrm{C}, \mathrm{C}-\mathrm{H})$. This provides a clear indication of the GA-crosslinking of the HA, taking into consideration GA molecular formula, $\mathrm{O}=\mathrm{HC}-\left(\mathrm{CH}_{2}\right)_{3}-\mathrm{CH}=\mathrm{O}$.

TABLE II. XPS Atomic Percentage (\%) of C, O, and Na Elements Present in the Tested Samples

\begin{tabular}{lccc}
\hline & \multicolumn{3}{c}{ Elements } \\
\cline { 2 - 4 } Samples & $\mathrm{C}_{1 \mathrm{~s}}$ & $\mathrm{O}_{1 \mathrm{~s}}$ & $\mathrm{Na}_{1 \mathrm{~s}}$ \\
\hline $\mathrm{HA}$ & $65.2 \%$ & $26.3 \%$ & $1.4 \%$ \\
$\mathrm{HAx}$ & $69.9 \%$ & $22.8 \%$ & $0.4 \%$ \\
\hline
\end{tabular}



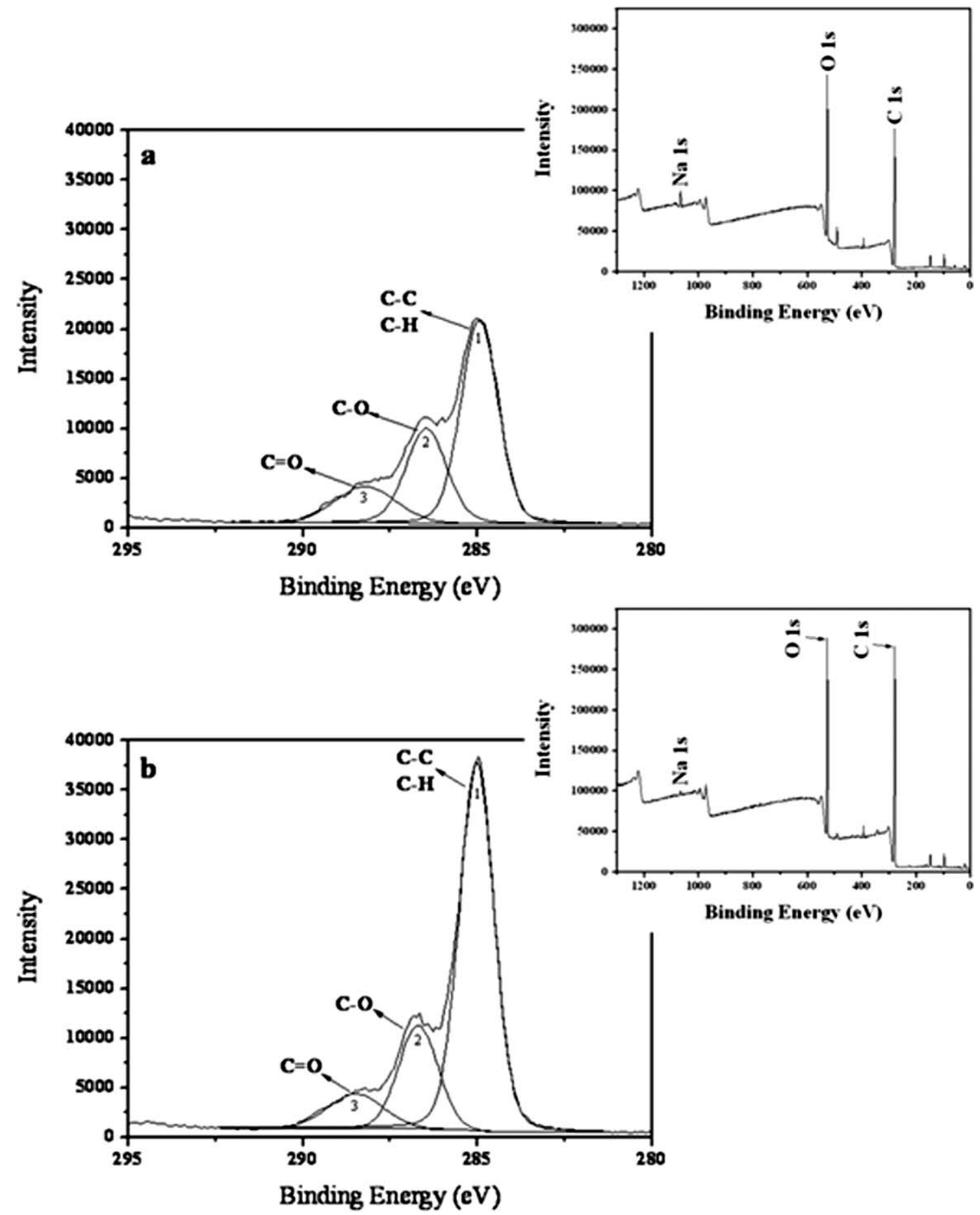

FIGURE 6. XPS $\mathrm{C}_{1 \mathrm{~s}}$ core level spectra of: (a) $1 \% \mathrm{HA}$ films and (b) $1 \% \mathrm{HAx}$ films. The inserted figures correspond to the survey scan spectra of $1 \% \mathrm{HA}$ and $1 \% \mathrm{HAx}$ films, respectively.

Mechanical analysis: Compression test. A proper mechanical characterization is among the most important physical tests that must be carried out, to evaluate if the materials are capable to withstand mechanical stresses in clinical use. $^{58}$ The mechanical analysis will dictate the viability of applying these materials in terms of their geometrical integrity at short term, determined by the elastic modulus and strength of the specimens to evaluate its potential as a bone tissue substitute. Figure 7 shows a slight increase of the elastic compression modulus $(E)$ values with increasing $\mathrm{HAx}$ concentration on the PLLA scaffolds. The $E$ value for the PLLA scaffolds was $23 \mathrm{MPa}$. With the HAx coating, the determined $E$ values are $35 \mathrm{MPa}$ for the PLLA/0.5HAx scaffolds and $36 \mathrm{MPa}$ for the PLLA/1HAx scaffolds. Only the $E$ values between PLLA and PLLA/0.5HAx, and between PLLA and PLLA/1HAx scaffolds are statistically significant 
TABLE III. Intensity of $\mathrm{C}-\mathrm{C}, \mathrm{C}-\mathrm{H}, \mathrm{C}-\mathrm{O}$, and $\mathrm{C}=\mathbf{0}$ peaks, Obtained from the XPS Spectra of $1 \% \mathrm{HA}$ and $1 \% \mathrm{HAx}$

\begin{tabular}{lcc}
\hline Sample & Peak Intensity & Assignments \\
\hline $1 \% \mathrm{HA}$ & 21,080 & $\mathrm{C}-\mathrm{C}, \mathrm{C}-\mathrm{H}$ \\
& 10,041 & $\mathrm{C}-\mathrm{O}$ \\
& 4156 & $\mathrm{C}=\mathrm{O}$ \\
$1 \% \mathrm{HAx}$ & 37,737 & $\mathrm{C}-\mathrm{C}, \mathrm{C}-\mathrm{H}$ \\
& 11,248 & $\mathrm{C}-\mathrm{O}$ \\
& 4423 & $\mathrm{C}=\mathrm{O}$ \\
\hline
\end{tabular}

$\left(^{*} p<0.05\right)$. The HA content is too small to greatly affect the mechanical properties of the hybrid scaffold, but it can be noted an enhancement of the stiffness of the materials probably due to the crosslinking bonds. ${ }^{34,35,50,59}$ This data demonstrated that the mechanical properties of the PLLA scaffolds in the same magnitude of others possessing the same material/processing technique and with similar porosity and pore size distribution. ${ }^{41,60}$

The complexity of the architecture and the variability of properties of bone tissue, as well as differences in age, nutritional state, activity (mechanical loading), and disease status of individuals establish a major challenge in fabricating scaffolds for bone TE that will meet the needs of specific repair sites in specific patients. ${ }^{5,61}$ The cortical bone is solid and dense, while the inner layer, cancellous bone, is a spongy honeycombed structure filled with blood vessels and bone marrow maximizing the strength to weight ratio for bending and compression loads. ${ }^{61}$ The elastic modulus of cancellous bone has values ranging from 20 to $50 \mathrm{MPa},{ }^{61}$ which are similar to the obtained results. Despite the mechanical properties of the developed scaffolds needs to be improved for the proposed applications, that is, cortical bone regeneration. A strategy that has been used to accomplish this goal consists on the reinforcement of the PLLA scaffolds with a ceramic material, such as hydroxyapatite.

\section{In vitro cell culture studies}

L929 adhesion, morphology, and assessment of cytotoxicity. The response of cells to biomaterials is often initiated by cell contact and adhesion to the biomaterial surface. ${ }^{62}$ In fact, cell behavior on a biomaterial depends on the surface properties, such as roughness, topography, wettability, charge, chemistry, and surface energy. ${ }^{2}$ In most cases, the cell adhesion to substrates or ECM components is regulated by specific cell surface receptors, proteins, and proteoglycans, which are either part of the matrix or have adsorbed onto the surface of the biomaterials from the culture media. The matrix adheres to the surface and cells then bind to the matrix via those receptors. ${ }^{62,63}$ Thus, the substrate influences cell attachment, adhesion, and spreading. ${ }^{62}$

L929 adhesion and morphology were investigated by SEM analysis after $24 \mathrm{~h}$ of culturing (Fig. 8). SEM micrographs of L929 reveals that cells were able to adhere and presented a flatten morphology, thus exhibiting a good adhesion to all substrates, both at the surface and core of the scaffolds. The attached cells presented a typical morphology for fibroblasts with an elongated shape. ${ }^{64}$ The seeding of cells onto porous PLLA normally do not provide difficulties, especially when slow degrading PLLA is used, as it is the case. $^{65}$ Moreover, with the HA, a glycosaminoglycan, the same is observable, even after the GA-crosslinking.

Figure 9 shows the cell viability assessed by carrying out the MTS test after $72 \mathrm{~h}$ of culturing. From the results it is possible to assess that cells are viable when cultured onto all the scaffolds. No significant differences on the L929 cytotoxicity of the different scaffolds are detected. By its turn, these data prove that the HA crosslinking with GA, with the additional glycine aqueous solution treatment, do not have any cytotoxic effect on L929 cells. Significant differences were also observed between the tissue culture polystyrene (TCPS) controls and the scaffolds. In addition, cell viability of the fibroblasts on PLLA/1HAx scaffolds significantly decreased $(p<0.05)$ as compared to that for PLLA and PLLA/0.05HAx scaffolds, which suggests that higher HA concentrations may inhibit cell viability. ${ }^{49}$ Surface roughness enhances attachment, proliferation, and differentiation of anchorage dependent bone forming cells, therefore, the results obtained were as expected. ${ }^{5}$ However, it was already stated that HA concentrations influence biocompatibility of a biomaterial, as only HA concentrations in certain range (0.01-0.1\%) can enhance the cell adhesion, migration, and proliferation. With HA concentrations above $0.1 \%$ it would reduce or even inhibit the effect. ${ }^{49}$ The present results corroborate these findings.

Comparing all SEM micrographs taken after $24 \mathrm{~h}$ with the ones taken after $72 \mathrm{~h}$ of in vitro culturing, it is notorious that $\mathrm{L} 929$ cells did not obstruct the pores of the scaffold at the surface, have perfectly adhered and grew favorably (Fig. 10). Besides spreading actively throughout all 3D scaffolds, these cells presented a flatten morphology. As it can be easily observed in Figure 10, L929 have also proliferated better

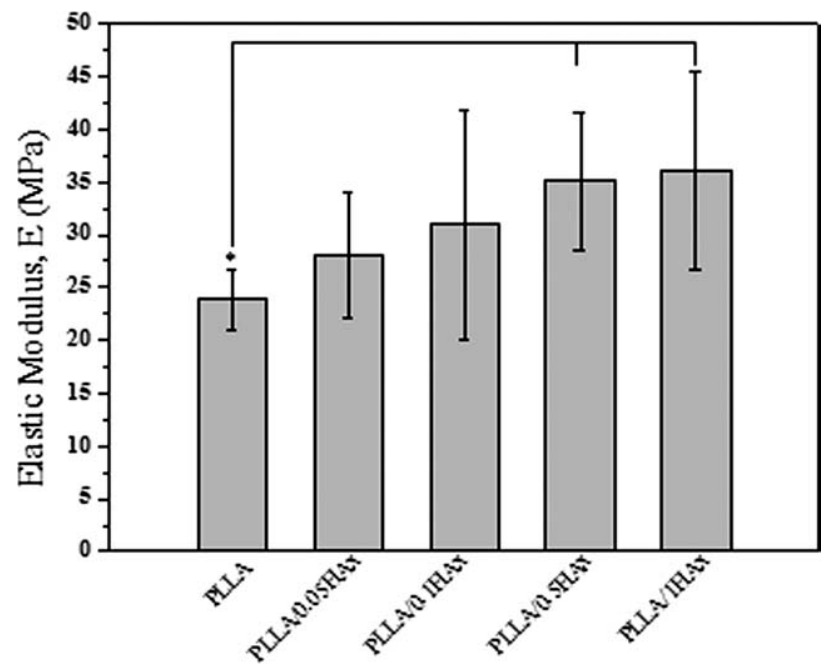

FIGURE 7. Elastic modulus ( $E, M P a$ ) of the PLLA, PLLA/0.05HAx, PLLA/0.1HAx, PLLA/0.5HAx, and PLLA/1HAx scaffolds, obtained from Compression Tests. Bars represent main statistical differences $(n=5$, $\left.{ }^{*} p<0.05\right)$ in comparison with PLLA scaffold. 


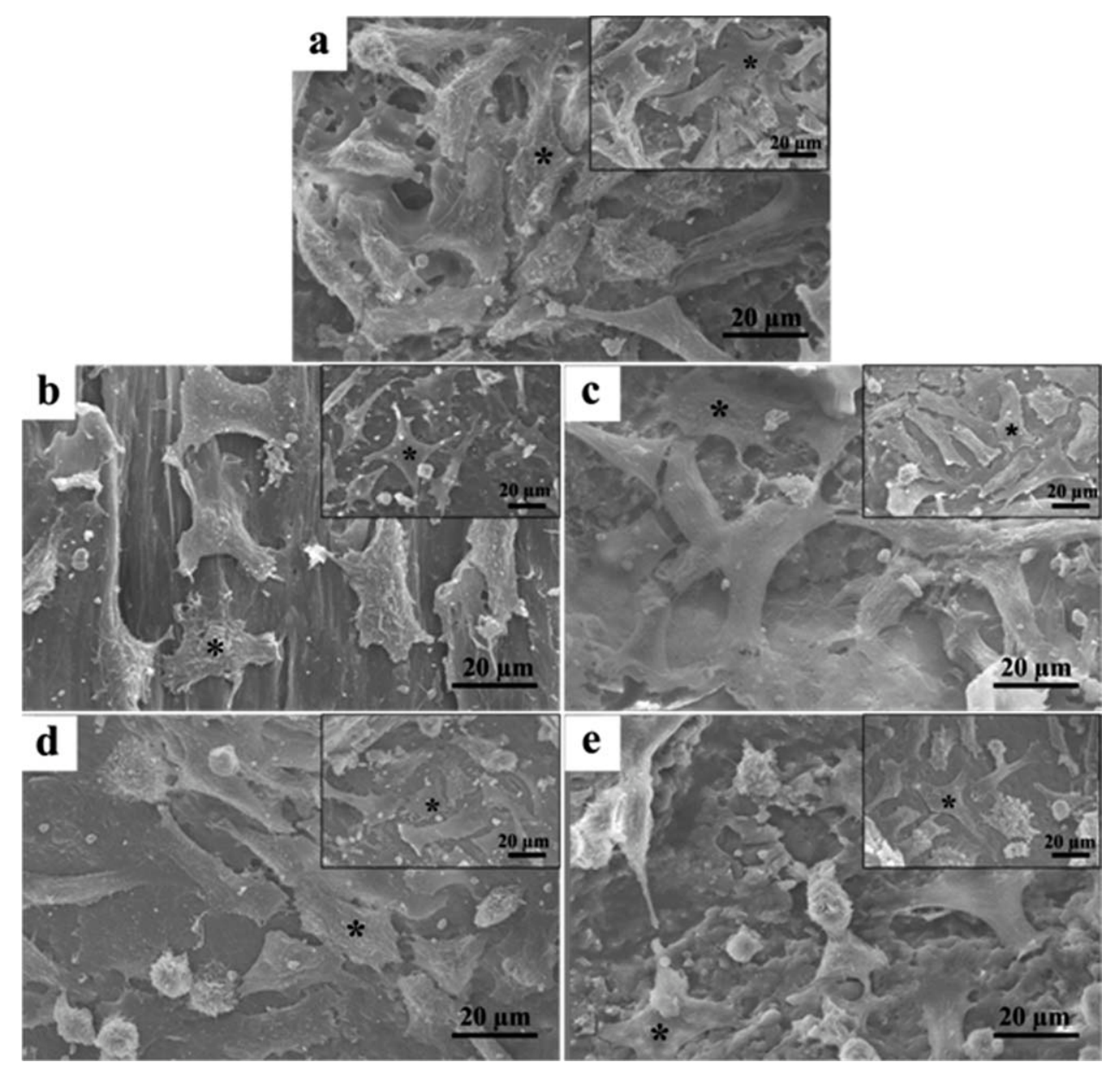

FIGURE 8. SEM micrographs of the surface of the different scaffolds seeded with L929 $\left(1 \times 10^{5}\right.$ cells per scaffold $)$ after $24 \mathrm{~h}$ of culturing: (a) PLLA, (b) PLLA/0.05HAx, (c) PLLA/0.1HAx, (d) PLLA/0.5HAx, and (e) PLLA/1HAx. The inserted images were taken from the cross section of the scaffolds, respectively. It is also possible to observe that cells perfectly adhere and present a flatten morphology $\left({ }^{*}\right)$.

on the scaffolds surface than on its cross section, except for areas with large and interconnected pores, even in the middle of the scaffolds, or in areas more close to the surface. It is clear that the different pore size did not affect cell penetration depth. ${ }^{5}$ Therefore, cells were able to penetrate deeper into the scaffold core, which greatly affects the overall performance of the construct and shows that scaffold architecture allowed cells in-growths and a sufficient diffusion of nutrients. ${ }^{45}$ In addition, the formation of cells micovilli is also observed, which is suggestive of cell activation. ${ }^{45}$

These data are quite promising and future cell culture studies combining the PLLA/HAx scaffolds and bone marrow stromal cells (BMSCs), for longer times of in vitro culturing, are envisioned to further elucidate the potential applications in bone TE scaffolding.

\section{CONCLUSIONS}

Bone is one of the tissues with the highest demand for regeneration, replacement, or reconstruction. Efforts in bone tissue engineering (TE) have aimed at mimic the extracellular matrix to help guide morphogenesis and tissue repair. In a step

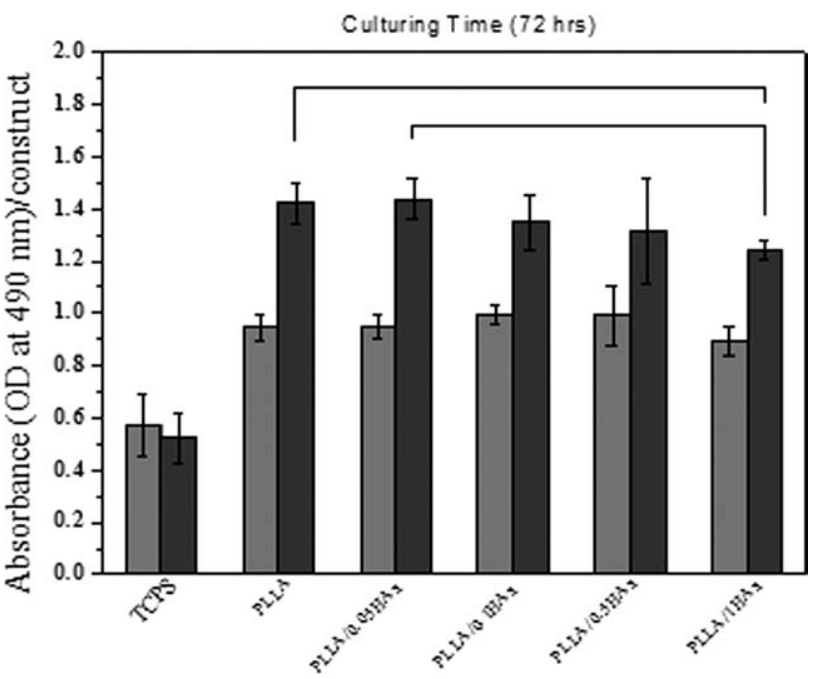

FIGURE 9. MTS test on the PLLA, PLLA/0.05HAx, PLLA/0.1HAx, PLLA/ $0.5 \mathrm{HAx}$, and PLLA/1HAx constructs, to determine L929 cell viability after culturing for $72 \mathrm{~h}$. Bars represent main statistical differences $(n=3, p<0.05)$. TCPS was used as control. 


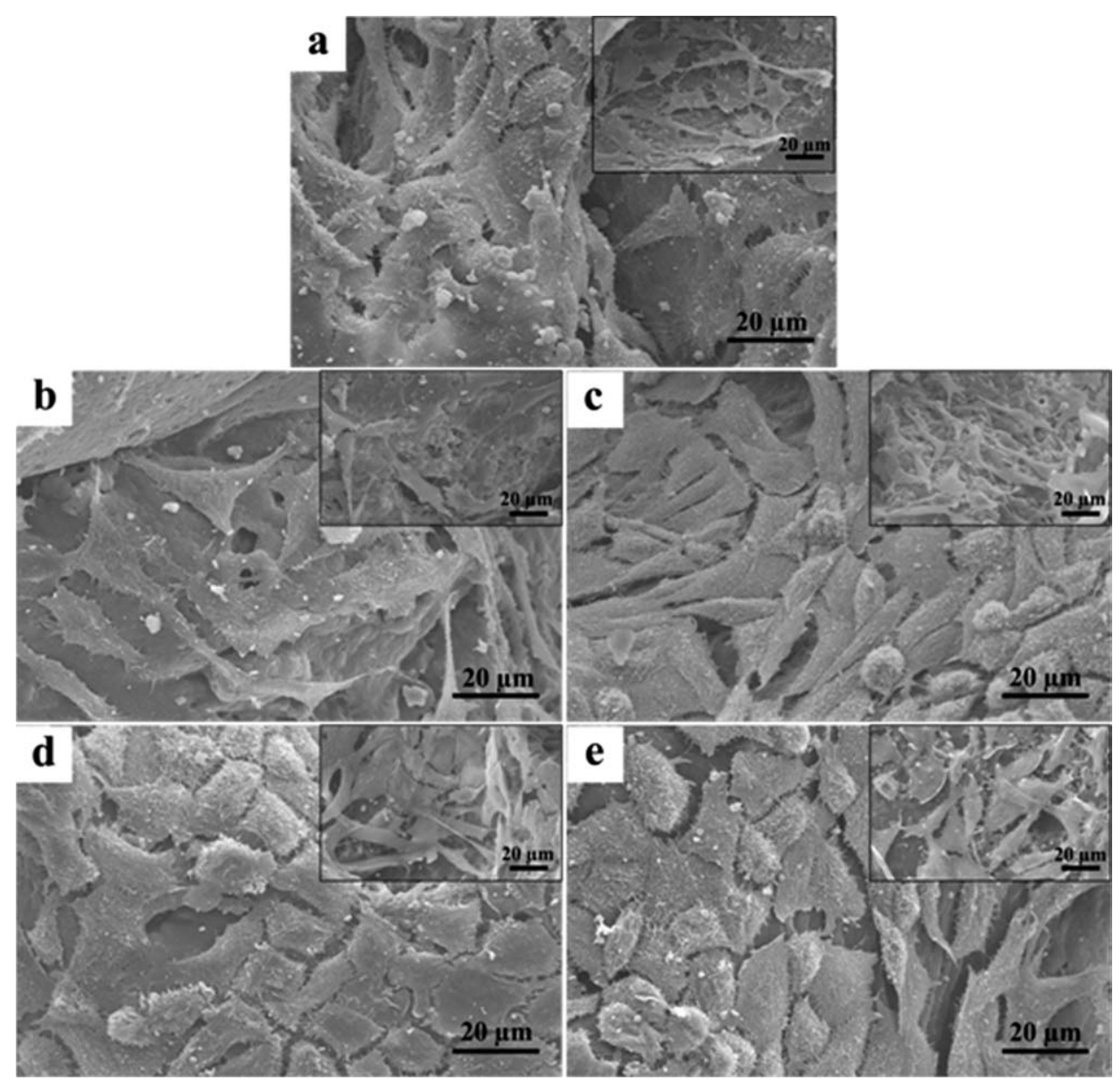

FIGURE 10. SEM micrographs of the surface of the different scaffolds seeded with L929 $\left(1 \times 10^{5}\right.$ cells per scaffold) after culturing for $72 \mathrm{~h}$. (a) PLLA, (b) PLLA/0.05HAx, (c) PLLA/0.1HAx, (d) PLLA/0.5HAx, and (e) PLLA/1HAx. The inserted images were taken from the cross section of the scaffolds, respectively.

forward addressing this challenge, novel poly(L-lactic acid) scaffolds coated with glutaraldehyde-crosslinked hyaluronic acid were developed. The crosslinking reaction was achieved in a recognizable and stable manner. The mechanical properties of the developed scaffolds showed high potential for bone TE. Preliminary cell culture studies showed that these scaffolds permitted mouse lung fibroblast cell line (L929) cells adhesion, cells in-growth and proliferation, forming a monolayer onto the PLLA/HAx scaffolds. In addition, the HA crosslinking with glutaraldehyde showed no negative effect, over L929 cells viability in vitro. However, as already stated, HA concentrations above $0.1 \%$ can reduce or even inhibit cells viability. Therefore, the developed glutaraldehyde-crosslinked hyaluronic acid/poly(L-lactic acid) hybrid scaffolds showed great promise for bone TE applications.

\section{ACKNOWLEDGMENTS}

The authors acknowledge the funding for research in the field of Regenerative Medicine through the collaboration agreement from the Conselleria de Sanidad (Generalitat Valenciana) and the Instituto de Salud Carlos III (Ministry of Science and Innovation). The European Union Financing, as part of the SOCRATES/Erasmus program is also gratefully acknowledged.

\section{References}

1. Navarro $M$, Michiardi $A$, Castano $O$, Planell JA. Biomaterials in orthopedics. J Royal Soc Interface 2008;5:1137-1158.

2. Olivier $V$, Faucheux $N$, Hardouin P. Biomaterial challenges and approaches to stem cell use in bone reconstructive surgery. Drug Discov Today 2004;9:803-811.

3. Stevens MM. Biomaterials for bone tissue engineering. Mater Today 2008;11:18-25.

4. Mano JF, Reis RL. Osteochondral defects: Present situation and tissue engineering approaches. J Tissue Eng Regenerat Med 2007;1:261-273.

5. Karageorgiou V, Kaplan D. Porosity of 3D biomaterial scaffolds and osteogenesis. Biomaterials 2005;26:5474-5491.

6. Lee $C T$, Huang CP, Lee YD. Biomimetic porous scaffolds made from poly(L-lactide)-g-chondroitin sulfate blend with poly(L-lactide) for cartilage tissue engineering. Biomacromolecules 2006;7: 2200-2209.

7. Gomes ME, Reis RL. Biodegradable polymers and composites in biomedical applications: From catgut to tissue engineering-Part 2-Systems for temporary replacement and advanced tissue regeneration. Int Mater Rev 2004;49:274-285.

8. Lee JW, Gardella JA. Surface perspectives in the biomedical applications of poly(alpha-hydroxy acid)s and their associated copolymers. Anal Bioanal Chem 2002;373:526-537.

9. Middleton JC, Tipton AJ. Synthetic biodegradable polymers as orthopedic devices. Biomaterials 2000;21:2335-2346.

10. Salgado AJ, Coutinho OP, Reis RL. Bone tissue engineering: State of the art and future trends. Macromol Biosci 2004;4: 743-765. 
11. Ghosh S, Viana JC, Reis RL, Mano JF. The double porogen approach as a new technique for the fabrication of interconnected poly(L-lactic acid) and starch based biodegradable scaffolds. J Mater Sci Mater Med 2007;18:185-193.

12. Li XM, Feng QL. Porous poly-L-lactic acid scaffold reinforced by chitin fibers. Polym Bull 2005;54:47-55.

13. Mano JF, Silva GA, Azevedo HS, Malafaya PB, Sousa RA, Silva SS, Boesel LF, Oliveira JM, Santos TC, Marques AP, Neves NM, Reis RL. Natural origin biodegradable systems in tissue engineering and regenerative medicine: Present status and some moving trends. J Royal Soc Interface 2007;4:999-1030.

14. Ma ZW, Mao ZW, Gao CY. Surface modification and property analysis of biomedical polymers used for tissue engineering. Colloids Surf B Biointerfaces 2007;60:137-157.

15. Lazzeri L, Cascone MG, Danti S, Serino LP, Moscato S, Bernardini N. Gelatine/PLLA sponge-like scaffolds: Morphological and biological characterization. J Mater Sci Mater Med 2007;18: 1399-1405.

16. Zhu YB, Sun Y. The influence of polyelectrolyte charges of polyurethane membrane surface on the growth of human endothelia cells. Colloids Surf B: Biointerfaces 2004;36:49-55.

17. Chung TW, Liu DZ, Wang SY, Wang SS. Enhancement of the growth of human endothelial cells by surface roughness at nanometer scale. Biomaterials 2003;24:4655-4661.

18. Wang YW, Wu $\mathrm{Q}$, Chen GQ. Reduced mouse fibroblast cell growth by increased hydrophilicity of microbial polyhydroxyalkanoates via hyaluronan coating. Biomaterials 2003;24:4621-4629.

19. Ma ZW, Gao CY, Ji JA, Shen JC. Protein immobilization on the surface of poly-L-lactic acid films for improvement of cellular interactions. Eur Polym J 2002;38:2279-2284.

20. Mano JF, Hungerford G, Gómez Ribelles JL. Bioactive poly(L-lactic acid)-chitosan hybrid scaffolds. Mater Sci Eng C 2008:28: 1356-1365.

21. Prabaharan M, Rodriguez-Perez MA, de Saja JA, Mano JF. Preparation and characterization of poly(L-lactic acid)-chitosan hybrid scaffolds with drug release capability. J Biomed Mater Res B: Appl Biomat 2007;81:427-434.

22. Segura T, Anderson BC, Chung PH, Webber RE, Shull KR, Shea LD. Crosslinked hyaluronic acid hydrogels: A strategy to functionalize and pattern. Biomaterials 2005;26:359-371.

23. Collins MN, Birkinshaw C. Comparison of the effectiveness of four different crosslinking agents with hyaluronic acid hydrogel films for tissue-culture applications. J Appl Polym Sci 2007;104: 3183-3191.

24. Tian WM, Zhang CL, Hou SP, Yu X, Cui FZ, Xu OY, Sheng SL, Cui $\mathrm{H}$, Li HD. Hyaluronic acid hydrogel as Nogo-66 receptor antibody delivery system for the repairing of injured rat brain: In vitro. J Control Release 2005;102:13-22.

25. Slevin M, Krupinski J, Gaffney J, Matou S, West D, Delisser H, Savani RC, Kumar S. Hyaluronan-mediated angiogenesis in vascular disease: Uncovering RHAMM and CD44 receptor signaling pathways. Matrix Biol 2007;26:58-68.

26. Ibrahim S, Ramamurthi A. Hyaluronic acid cues for functional endothelialization of vascular constructs. J Tissue Eng Regener Med 2008;2:22-32.

27. Collier JH, Camp JP, Hudson TW, Schmidt CE. Synthesis and characterization of polypyrrole-hyaluronic acid composite biomaterials for tissue engineering applications. J Biomed Mater Res 2000;50:574-584.

28. Chen WEJ, Abatangelo G. Functions of hyaluronan in wound repair. Wound Repair Regener 1999;7:79-89.

29. Moon JJ, West JL. Vascularization of engineered tissues: Approaches to promote angiogenesis in biomaterials. Curr Topics Med Chem 2008;8:300-310.

30. Cao GY, Savani RC, Fehrenbach M, Lyons C, Zhang L, Coukos G, DeLisser HM. Involvement of endothelial CD44 during in vivo angiogenesis. Am J Pathology 2006;169:325-336.

31. Peattie RA, Rieke ER, Hewett EM, Fisher RJ, Shu XZ, Prestwich GD. Dual growth factor-induced angiogenesis in vivo using hyaIuronan hydrogel implants. Biomaterials 2006;27:1868-1875.

32. Collins MN, Birkinshaw C. Investigation of the swelling behavior of crosslinked hyaluronic acid films and hydrogels produced using homogeneous reactions. J Appl Polym Sci 2008;109: 923-931.
33. Tomihata K, Ikada $\mathrm{Y}$. Crosslinking of hyaluronic acid with glutaraldehyde. J Polym Sci Part A: Polym Chem 1997;35: 3553-3559.

34. Jeon O, Song SJ, Lee KJ, Park MH, Lee SH, Hahn SK, Kim S, Kim B-S. Mechanical properties and degradation behaviors of hyaluronic acid hydrogels cross-linked at various cross-linking densities. Carbohydr Polym 2007;70:251-257.

35. Couet F, Rajan N, Mantovani D. Macromolecular biomaterials for scaffold-based vascular tissue engineering. Macromol Biosci 2007:7:701-718.

36. Chen GP, Sato T, Ohgushi H, Ushida T, Tateishi T, Tanaka J. Culturing of skin fibroblasts in a thin PLGA-collagen hybrid mesh. Biomaterials 2005;26:2559-2566.

37. Gough JE, Scotchford CA, Downes S. Cytotoxicity of glutaraldehyde crosslinked collagen/poly(vinyl alcohol) films is by the mechanism of apoptosis. J Biomed Mater Res A 2002;61:121-130.

38. Park H, Temenoff JS, Tabata Y, Caplan Al, Mikos AG. Injectable biodegradable hydrogel composites for rabbit marrow mesenchymal stem cell and growth factor delivery for cartilage tissue engineering. Biomaterials 2007;28:3217-3227.

39. Wu HC, Wang TW, Kang PL, Tsuang YH, Sun JS, Lin FH. Coculture of endothelial and smooth muscle cells on a collagen membrane in the development of a small-diameter vascular graft. Biomaterials 2007;28:1385-1392.

40. Ghosh S, Viana JC, Reis RL, Mano JF. Osteochondral tissue engineering constructs with a cartilage part made of poly(L-lactic acid) starch blend and a bioactive poly(L-lactic acid) composite layer for subchondral bone. Bioceramics 2006;18 (Parts 1 and 2):309-311: 1109-1112.

41. Ghosh S, Viana JC, Reis RL, Mano JF. Bi-layered constructs based on poly(L-lactic acid) and starch for tissue engineering of osteochondral defects. Mater Sci Eng C: Biomimetic Supramol Syst 2008;28:80-86.

42. Delpouve N, Saiter A, Mano JF, Dargent E. Cooperative rearranging region size in semi-crystalline poly(L-lactic acid). Polymer 2008:49:3130-3135.

43. Lebourg M, Serra RS, Estelles JM, Sanchez FH, Ribelles JLG, Anton JS. Biodegradable polycaprolactone scaffold with controlled porosity obtained by modified particle-leaching technique. J Mater Sci Mater Med 2008;19:2047-2053.

44. Oliveira JM, Sousa RA, Kotobuki N, Tadokoro M, Hirose M, Mano $\mathrm{JF}$, Reis RL, Ohgushi $\mathrm{H}$. The osteogenic differentiation of rat bone marrow stromal cells cultured with dexamethasone-loaded carboxymethylchitosan/poly(amidoamine) dendrimer nanoparticles. Biomaterials 2009;30:804-813.

45. Oliveira JM, Rodrigues MT, Silva SS, Malafaya PB, Gomes ME, Viegas CA, Dias IR, Azevedo JT, Mano JF, Reis RL. Novel hydroxyapatite/chitosan bilayered scaffold for osteochondral tissueengineering applications: Scaffold design and its performance when seeded with goat bone marrow stromal cells. Biomaterials 2006;27:6123-6137.

46. Lee SH, Kim BS, Kim SH, Kang SW, Kim YH. Thermally produced biodegradable scaffolds for cartilage tissue engineering. Macromol Biosci 2004;4:802-810.

47. Hutmacher DW. Scaffolds in tissue engineering bone and cartilage. Biomaterials 2000;21:2529-2543.

48. Eisenbarth E. Biomaterials for tissue engineering. Adv Eng Mater 2007;9:1051-1060.

49. Liu HF, Yin YJ, Yao KD, Ma DR, Cui L, Cao YL. Influence of the concentrations of hyaluronic acid on the properties and biocompatibility of Cs-Gel-HA membranes. Biomaterials 2004;25: 3523-3530.

50. Mao JS, Liu HF, Yin YJ, Yao KD. The properties of chitosan-gelatin membranes and scaffolds modified with hyaluronic acid by different methods. Biomaterials 2003;24:1621-1629.

51. Melrose J, Smith SM, Appleyard RC, Little CB. Aggrecan, versican and type $\mathrm{VI}$ collagen are components of annular translamellar crossbridges in the intervertebral disc. Eur Spine J 2008;17: 314-324.

52. Tillman J, Ullm A, Madihally SV. Three-dimensional cell colonization in a sulfate rich environment. Biomaterials 2006:27:5618-5626.

53. Gliko-Kabir I, Penhasi A, Rubinstein A. Characterization of crosslinked guar by thermal analysis. Carbohydr Res 1999;316:6-13. 
54. Khutoryanskaya OV, Khutoryanskiy VV, Pethrick RA. Characterization of blends based on hydroxyethylcellulose and maleic acid-alt-methyl vinyl ether. Macromol Chem Phys 2005;206: 1497-1510.

55. Deng Y, Liu DR, Du GC, Li XF, Chen J. Preparation and characterization of hyaluronan/chitosan scaffold crosslinked by 1-ethyl-3-(3dimethylaminopropyl) carbodiimide. Polym Int 2007;56:738-745.

56. Kim SJ, Lee CK, Lee YM, Kim IY, Kim SI. Electrical $/ \mathrm{pH}$-sensitive swelling behavior of polyelectrolyte hydrogels prepared with hyaluronic acid-poly(vinyl alcohol) interpenetrating polymer networks. React Funct Polym 2003;55:291-298.

57. Kwon YN, Tang CY, Leckie JO. Change of chemical composition and hydrogen bonding behavior due to chlorination of crosslinked polyamide membranes. J Appl Polym Sci 2008;108: 2061-2066.

58. Reis RL, San Roman J. Biodegradable Systems in Tissue Engineering and Regenerative Medicine. Boca Raton: CRC Press; 2005.

59. Falcone SJ, Berg RA. Crosslinked hyaluronic acid dermal fillers: A comparison of rheological properties. J Biomed Mater Res Part A 2008:87:264-271.
60. Ghosh S, Gutierrez V, Fernández C, Rodriguez-Perez MA, Viana JC, Reis RL, Mano JF. Dynamic mechanical behavior of starchbased scaffolds in dry and physiologically simulated conditions: Effect of porosity and pore size. Acta Bioamaterialia 2008;4: 950-959.

61. Leong KF, Chua CK, Sudarmadji N, Yeong WY. Engineering functionally graded tissue engineering scaffolds. J Mech Behav Biomed Mater 2008;1:140-152.

62. Yliperttula M, Chung BG, Navaladi A, Manbachi A, Urtti A. Highthroughput screening of cell responses to biomaterials. Eur $\mathrm{J}$ Pharm Sci 2008;35:151-160.

63. Freshney RI. Culture of Animal Cells: A Manual of Basic Technique. Hoboken: John Wiley \& Sons, Inc.; 2005.

64. Silva SS, Luna SM, Gomes ME, Benesch J, Pashkuleva I, Mano JF, Reis RL. Plasma surface modification of chitosan membranes: Characterization and preliminary cell response studies. Macromol Biosci 2008;8:568-576.

65. Habraken W, Wolke JGC, Jansen JA. Ceramic composites as matrices and scaffolds for drug delivery in tissue engineering. Adv Drug Deliv Rev 2007;59:234-248. 